\title{
Trace elements in the statoliths of jumbo flying squid off the Exclusive Economic Zones of Chile and Peru
}

\author{
Bilin Liu ${ }^{1,2}$, Xinjun Chen ${ }^{1,2, *}$, Yong $\mathrm{Chen}^{2,3}$, Huajie $\mathrm{Lu}^{1}$, Weiguo Qian ${ }^{1,2}$ \\ ${ }^{1}$ College of Marine Sciences, Shanghai Ocean University, Hucheng Ring Road 999, Lingang New City, Shanghai 201306, \\ PR China \\ ${ }^{2}$ The Key Laboratory of Sustainable Exploitation of Oceanic Fisheries Resources, Ministry of Education, \\ 999 Hucheng Ring Road, Shanghai 201306, PR China \\ ${ }^{3}$ School of Marine Sciences, University of Maine, Orono, Maine 04469, USA
}

\begin{abstract}
Ontogenetic variation in 4 trace element $\left({ }^{88} \mathrm{Sr},{ }^{137} \mathrm{Ba},{ }^{24} \mathrm{Mg},{ }^{23} \mathrm{Na}\right)$ concentrations and their ratios to Ca were measured in statoliths of the jumbo flying squid Dosidicus gigas off the Exclusive Economic Zone of Chilean and Peruvian waters using laser ablation inductively coupled plasma mass spectrometry (LA-ICP-MS). The element compositions of statoliths showed no significant differences between females and males. All of the elements in different growth zones showed significant variations, except for $\mathrm{Mg}$. Sr:Ca and $\mathrm{Mg}$ :Ca were good indicators for distinguishing squid from autumn and winter spawning seasons. Sr:Ca and Ba:Ca distribution patterns in statoliths confirmed that paralarvae and juvenile squid inhabit surface waters, while subadult squid migrate into deeper waters. An increasing Sr:Ca ratio of subadult squid could be explained by declining temperature gradients from northern to southern sampling locations, although no significant Sr:Ca differences were observed ( $p>0.05)$. Mg:Ca ratios decreased progressively from the nucleus to the peripheral zone, which might be correlated with statolith growth rates. Na:Ca ratios slightly declined from paralarvae to the subadult phase. Quantitative relationships between statolith trace elements and environmental conditions under different growth stages are needed to improve our understanding of life history of D. gigas.
\end{abstract}

KEY WORDS: Dosidicus gigas $\cdot$ Life history $\cdot$ Chile $\cdot$ Peru $\cdot$ Strontium $\cdot$ Barium $\cdot$ Magnesium $\cdot$ Sodium Resale or republication not permitted without written consent of the publisher

\section{INTRODUCTION}

The jumbo flying squid Dosidicus gigas (d'Orbigny, 1835) is the most abundant and the largest ommastrephid widely distributed in the eastern Pacific Ocean from California $\left(37^{\circ} \mathrm{N}\right)$ to southern Chile $\left(47^{\circ} \mathrm{S}\right)$; its distribution extends westward to $125^{\circ} \mathrm{W}$ around the Equator (Nesis 1983, Nigmatullin et al. 2001). The highest abundance is found between the Gulf of California and waters off northern Chile, especially off the Peruvian coast (Nigmatullin et al. 2001). D. gigas supports one of the most important cephalopod fisheries in the eastern Pacific Ocean. During 2004 to 2008, annual global catches of D. gigas were about $787000 \mathrm{t}$, mainly by Peru, Mexico, Chile and China. The Chinese squid jigging fleet began targeting D. gigas in 2002, with annual landings reaching 50000 to 205000 t during 2002 to 2008.

In Chilean waters, Dosidicus gigas are landed yearround, supporting 1 of the 3 cephalopod fisheries (i.e. Loligo gahi, Octopus mimus, and D. gigas; Rocha 1997, Rocha \& Vega 2003, Zúñiga et al. 2008). D. gigas are mainly concentrated in waters off central Chile, where the estimated biomass in 2005 and 2006 was over 
130000 t (Alarcón-Muñoz et al. 2008). Spatial and temporal changes in size structure and reproductive activity of $D$. gigas were analyzed in the central-southern area off Chile $\left(34^{\circ}\right.$ to $\left.40^{\circ} \mathrm{S}\right)$, and variability may have resulted from migration of the species (Ibáñez \& Cubillos 2007). In waters outside the Exclusive Economic Zone (EEZ), D. gigas have been targeted by the Chinese squid jigging vessels since 2004 (Chen \& Zhao 2005). Three scientific surveys for the squid were made during 2006 to 2008 (Liu et al. 2010b). In Peruvian waters, many studies have been conducted to improve our understanding of the basic fisheries biology of D. gigas (e.g. Argüelles et al. 2001, Tafur et al. 2001, Taipe et al. 2001).

Cephalopod statoliths are calcified structures within the paired statocysts, which provide a sense of balance (Arkhipkin \& Bizikov 2000) and also act as an acceleration receptor; the statocyst provides much information about biology and ecology over an organism's life span (Arkhipkin 2005). Therefore, statoliths are perhaps best suitable for analyzing age and growth of cephalopods (Jackson 1994). Recently, geochemical signatures based on composition of trace elements and isotopes of calcified structures have become increasingly popular as a tool for investigating population structure and habitats (Thorrold et al. 2002), and are widely used in coral skeletons, bivalve shells, gastropods, and fish otoliths (Beck et al. 1992, Campana 1999, Zacherl et al. 2003a, Becker et al. 2005). Statoliths share many similarities in geochemistry and structure with fish otoliths, and the elemental composition of statoliths may represent a useful source of information on cephalopod habitats (Clarke 1978, Radtke 1983, Arkhipkin et al. 2004).

The chemical composition of cephalopod statoliths is important for discriminating different populations, analyzing life history, and reconstructing habitat environmental conditions (Liu et al. 2010a). Statolith signatures have been used to distinguish stocks of the Patagonian longfin squid Loligo gahi (Arkhipkin et al. 2004) and to determine life histories of sevenstar flying squid Martialia hyadesi (Rodhouse et al. 1994), Japanese common squid Todarodes pacificus (Ikeda et al. 1996, 2003), neon flying squid Ommastrephes bartrami (Yatsu et al. 1998), veined squid L. forberi (Biemann \& Piatkowski 2001), and boreoatlantic armhook squid Gonatus fabricii (Zumholz 2005). Previous results have shown the association of different elements with environmental conditions, especially water temperature; some of these elements (e.g. $\mathrm{Sr}, \mathrm{Fe}$, and $\mathrm{Zn}$ ) are considered 'thermometers' for reconstructing environment temperature. For $T$. pacificus, a negative relationship is observed between $\mathrm{Sr}$ concentration in statoliths and water temperature, whereas Fe and $\mathrm{Zn}$ show positive relation- ships (Ikeda et al. 1996). Several trace element concentrations in Dosidicus gigas statoliths were measured by particle induced X-ray emission (PIXE) in Peruvian and Costa Rican waters during El Niño and non-El Niño years, with no significant difference being found in $\mathrm{Sr}$ concentration despite higher water temperatures in El Niño years (Ikeda et al. 2002b). However, the difference in the $\mathrm{Sr}$ concentration between samples from the 2 waters is positively related to salinity (Ikeda et al. 2002b).

In our study we applied laser ablation inductively coupled plasma mass spectrometry (LA-ICP-MS) to determine element concentrations and ratios of calcium, strontium, barium, magnesium and sodium in the different zones of Dosidicus gigas statoliths collected from the waters outside EEZs of Chile and Peru, to quantify the composition and spatial distribution of these elements in the statolith, and to compare these elements among squid spawning in different seasons and collected from different locations. The information derived can improve our understanding of the life history of $D$. gigas.

\section{MATERIALS AND METHODS}

Squid collection. Fourteen specimens of Dosidicus gigas were sampled by the Chinese jigging fleet during scientific surveys from 2007 to 2008 in waters outside the EEZ of Chile, and another 4 were collected by industrial vessels in the waters outside the EEZ of Peru (Fig. 1, Table 1). Squid were measured on board for mantle length (ML) to the nearest $1 \mathrm{~mm}$ and body weight (BW) to the nearest $1 \mathrm{~g}$. Sex was identified and maturity stages were determined by eye on a scale of 1 to 5 (Lipinski 1979). Statoliths were dissected and stored in $90 \%$ alcohol for further analysis. A detailed description of all specimens used in this study is given in Table 1.

Age estimation and hatching date calculation. In total, 18 paired statoliths were extracted. Only the left one, if not damaged, was prepared for age estimation and element analysis. We followed standard aging methodology (Dawe \& Natsukari 1991). The number of increments for each statolith was counted independently by 2 readers. The average was used if the range of counts was within $10 \%$ of the mean (Yatsu et al. 1997).

Element analysis. After aging, the statolith sections were rinsed in MilliQ water for further element analysis. Several spots of analysis were set from the core to the edge of the dorsal dome for each statolith (Fig. 2). The first point was placed in the nucleus $(\mathrm{N})$, while the second point was in the postnuclear zones $(\mathrm{PN})$, representing the embryonic and larval phases, 


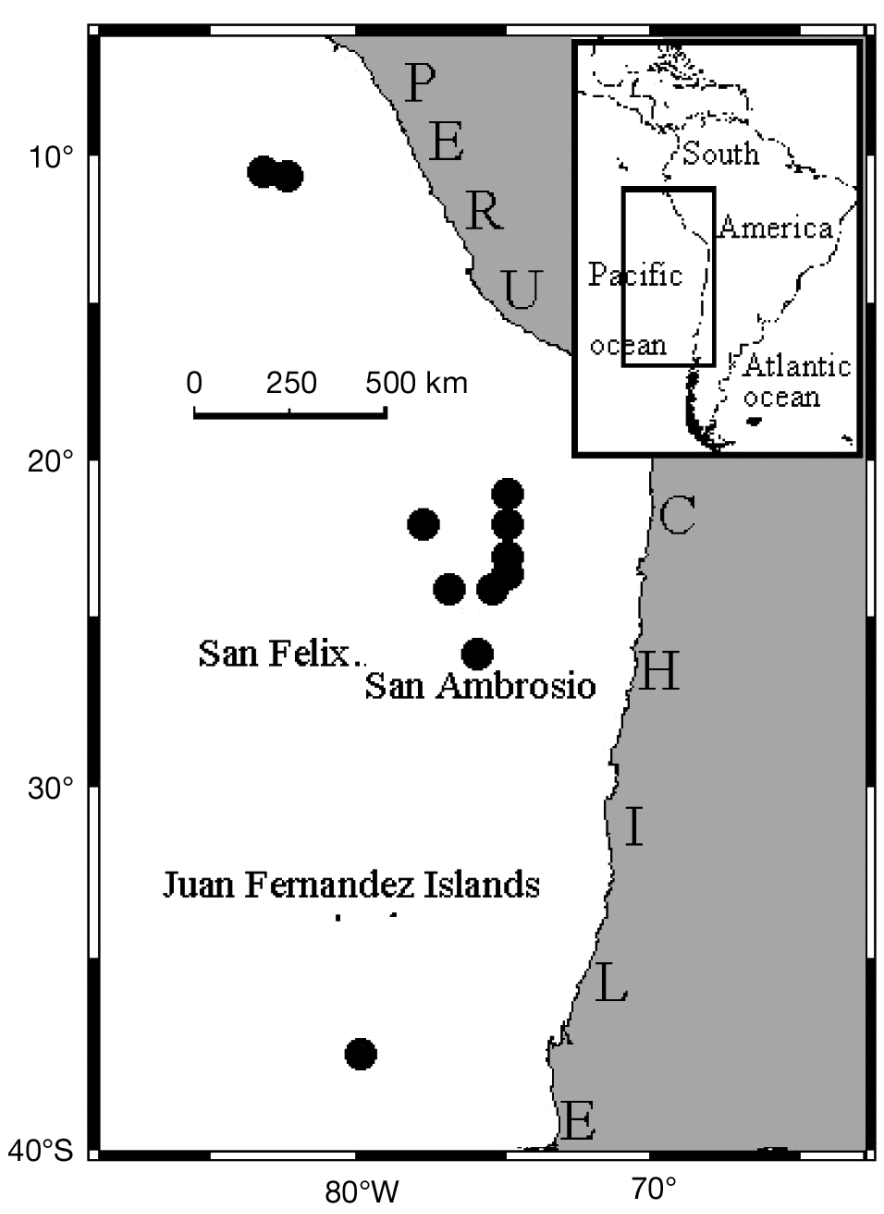

Fig. 1. Dosidicus gigas. Sampling locations (O) off the Exclusive Economic Zones of Chile and Peru respectively (Arkhipkin 2005). Two to 4 points were in the dark zone (DZ), representing the juvenile phase, and 1 to 5 points were placed in the peripheral zone (PZ), representing the subadult phase (Arkhipkin 2005).

Five elements $\left({ }^{43} \mathrm{Ca},{ }^{88} \mathrm{Sr},{ }^{137} \mathrm{Ba},{ }^{24} \mathrm{Mg},{ }^{23} \mathrm{Na}\right)$ were determined by LA-ICP-MS at the State Key Laboratory of Geological Processes and Mineral Resources, China University of Geosciences, using a $193 \mathrm{~nm}$ frequencyquadrupled ArF exciter laser coupled with Agilent 7500a. Ablation parameters in the analyses included a spot size of $24 \mu \mathrm{m}$ and a laser pulse of $5 \mathrm{~Hz}$. Helium $\left(0.7 \mathrm{l} \mathrm{min}^{-1}\right)$ was used as the sample gas in the ablation cell, and Argon (0.8 $1 \mathrm{~min}^{-1}$ ) was subsequently added to the gas flow. Every spot in the statoliths was ablated for $20 \mathrm{~s}$ to determine 5 elements.

Statistical analysis. Two-way analysis of variance (ANOVA) was used to test for significant differences in element:Ca ratios among specimens and between the statolith growth zones.

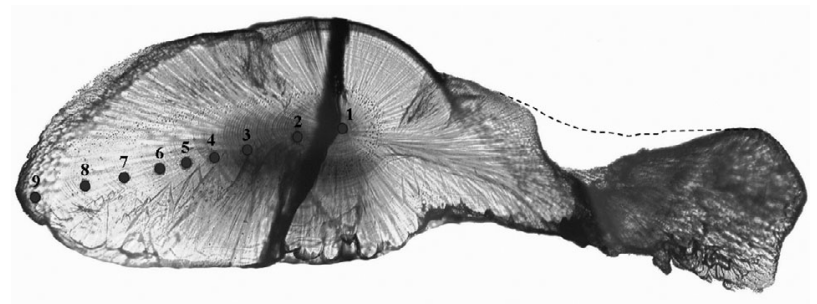

Fig. 2. Dosidicus gigas. Ground statolith, showing spots of analysis: $1=$ nucleus; 2 = postnuclear zone; 3 to $6=$ dark zone; and 7 to $9=$ peripheral zone

Table 1. Dosidicus gigas. Summary information of sampled squid. SST: sea surface temperature, ML: mantle length, BW: body weight, nd: no data, o: female, ơ : male. Maturity was based on a scale of 1 to 5 following Lipinski (1979). Dates are given as yyyy/mm/dd

\begin{tabular}{|c|c|c|c|c|c|c|c|c|c|c|c|}
\hline No. & $\begin{array}{l}\text { Sample } \\
\text { date }\end{array}$ & $\begin{array}{l}\text { Sample } \\
\text { area }\end{array}$ & Sample location & $\begin{array}{l}\text { SST } \\
\left({ }^{\circ} \mathrm{C}\right)\end{array}$ & $\begin{array}{c}\mathrm{ML} \\
(\mathrm{mm})\end{array}$ & $\begin{array}{l}\text { BW } \\
(\mathrm{g})\end{array}$ & Sex & $\begin{array}{l}\text { Maturity } \\
\text { stage }\end{array}$ & $\begin{array}{l}\text { Age } \\
\text { (d) }\end{array}$ & $\begin{array}{l}\text { Spawning } \\
\text { date }\end{array}$ & $\begin{array}{c}\text { Spawning } \\
\text { season }\end{array}$ \\
\hline $6 \mathrm{~b}$ & $2007 / 01 / 20$ & Central & $77^{\circ} 00^{\prime} \mathrm{W}, 24^{\circ} 00^{\prime} \mathrm{S}$ & 20.84 & 391 & 1800 & 우 & 1 & 237 & $2006 / 05 / 28$ & Autumn \\
\hline $23 b$ & $2007 / 01 / 21$ & Central & $76^{\circ} 00^{\prime} \mathrm{W}, 26^{\circ} 00^{\prime} \mathrm{S}$ & 21.44 & 425 & 2250 & o & 1 & 251 & $2006 / 05 / 15$ & Winter \\
\hline $35 b$ & $2007 / 01 / 25$ & South & $80^{\circ} 00^{\prime} \mathrm{W}, 37^{\circ} 30^{\prime} \mathrm{S}$ & 18.21 & 368 & 1350 & o & 1 & 201 & $2006 / 07 / 08$ & Winter \\
\hline $38 \mathrm{~b}$ & $2007 / 01 / 25$ & South & $80^{\circ} 00^{\prime} \mathrm{W}, 37^{\circ} 30^{\prime} \mathrm{S}$ & 18.21 & 309 & 800 & 오 & 1 & 207 & $2006 / 07 / 02$ & Autumn \\
\hline $61 \mathrm{a}$ & $2008 / 05 / 01$ & Central & $75^{\circ} 00^{\prime} \mathrm{W}, 23^{\circ} 00^{\prime} \mathrm{S}$ & nd & 381 & 1643 & $\begin{array}{l}\text { f } \\
\text { Q }\end{array}$ & 1 & 216 & $2007 / 09 / 28$ & Spring \\
\hline $69 b$ & $2008 / 05 / 01$ & Central & $75^{\circ} 00^{\prime} \mathrm{W}, 23^{\circ} 00^{\prime} \mathrm{S}$ & nd & 361 & 1302 & $\sigma^{t}$ & 1 & 235 & 2007/09/09 & Spring \\
\hline $88 a$ & $2008 / 05 / 07$ & Central & $77^{\circ} 50^{\prime} \mathrm{W}, 22^{\circ} 00^{\prime} \mathrm{S}$ & nd & 449 & 2735 & $0^{7}$ & 2 & 242 & 2007/09/08 & Spring \\
\hline $75 b$ & $2008 / 05 / 07$ & Central & $77^{\circ} 50^{\prime} \mathrm{W}, 22^{\circ} 00^{\prime} \mathrm{S}$ & nd & 517 & 3719 & \% & 2 & 191 & $2007 / 10 / 29$ & Spring \\
\hline $321 a$ & 2008/05/09 & Central & $75^{\circ} 30^{\prime} \mathrm{W}, 24^{\circ} 00^{\prime} \mathrm{S}$ & nd & 372 & 1535 & $0^{+}$ & 1 & 217 & 2007/10/05 & Spring \\
\hline $316 a$ & $2008 / 05 / 11$ & Central & $75^{\circ} 00^{\prime} \mathrm{W}, 23^{\circ} 30^{\prime} \mathrm{S}$ & nd & 341 & 1338 & $0^{7}$ & 1 & 248 & 2007/09/06 & Spring \\
\hline $294 a$ & $2008 / 05 / 12$ & Central & $75^{\circ} 00^{\prime} \mathrm{W}, 22^{\circ} 00^{\prime} \mathrm{S}$ & nd & 391 & 1978 & \% & 1 & 184 & $2007 / 11 / 10$ & Spring \\
\hline $301 a$ & $2008 / 05 / 12$ & Central & $75^{\circ} 00^{\prime} \mathrm{W}, 22^{\circ} 00^{\prime} \mathrm{S}$ & nd & 401 & 2127 & o & 1 & 291 & $2007 / 07 / 26$ & Winter \\
\hline $164 \mathrm{~b}$ & $2008 / 05 / 12$ & Central & $75^{\circ} 00^{\prime} \mathrm{W}, 22^{\circ} 00^{\prime} \mathrm{S}$ & nd & 402 & 1789 & 오 & 1 & 202 & $2007 / 10 / 23$ & Spring \\
\hline $49 b$ & $2008 / 05 / 14$ & Central & $75^{\circ} 00^{\prime} \mathrm{W}, 21^{\circ} 00^{\prime} \mathrm{S}$ & nd & 373 & 1457 & $o^{7}$ & 1 & 209 & $2007 / 10 / 18$ & Spring \\
\hline $124 \mathrm{~b}$ & 2008/09/13 & North & $82^{\circ} 29^{\prime} \mathrm{W}, 10^{\circ} 39^{\prime} \mathrm{S}$ & nd & 122 & 533 & 오 & 1 & 159 & $2007 / 04 / 07$ & Autumn \\
\hline $140 \mathrm{~b}$ & 2008/09/13 & North & $82^{\circ} 29^{\prime} \mathrm{W}, 10^{\circ} 39^{\prime} \mathrm{S}$ & nd & 275 & 549 & 오 & 1 & 164 & $2007 / 04 / 02$ & Autumn \\
\hline $61 b$ & $2008 / 09 / 20$ & North & $83^{\circ} 14^{\prime} \mathrm{W}, 10^{\circ} 32^{\prime} \mathrm{S}$ & nd & 258 & 456 & $\begin{array}{l}7 \\
\text { q }\end{array}$ & 1 & 159 & $2007 / 04 / 07$ & Autumn \\
\hline $70 \mathrm{~b}$ & $2008 / 09 / 20$ & North & $83^{\circ} 14^{\prime} \mathrm{W}, 10^{\circ} 32^{\prime} \mathrm{S}$ & nd & 291 & 735 & o & 1 & 176 & $2007 / 03 / 28$ & Autumn \\
\hline
\end{tabular}


Table 2. Dosidicus gigas. Element concentrations and element:Ca ratios in statoliths analyzed using laser ablation inductively coupled plasma mass spectrometry (LA-ICP-MS), means $\pm \mathrm{SD}$

\begin{tabular}{|lccccc|}
\hline \multirow{2}{*}{ Element } & \multicolumn{2}{c}{ Concentration (ppm) } & \multicolumn{2}{c|}{ Element:Ca ratio } \\
& Range & Mean & Range & Mean \\
\hline Strontium & $5871-6570$ & $6186 \pm 213$ & $14.8-16.4 \mathrm{mmol} \mathrm{mol}^{-1}$ & $15.6 \pm 0.5$ \\
Barium & $4.5-9.5$ & $6.7 \pm 1.5$ & $11.2-23.8 \mathrm{~mol} \mathrm{~mol}^{-1}$ & $16.8 \pm 3.9$ \\
Magnesium & $30.9-93.9$ & $61.3 \pm 19.3$ & $79-233 \mu \mathrm{mol} \mathrm{mol}^{-1}$ & $154 \pm 48$ \\
Sodium & $3382-5115$ & $4174 \pm 584$ & $8.6-12.8 \mathrm{mmol} \mathrm{mol}^{-1}$ & $10.5 \pm 1.4$ \\
\hline
\end{tabular}

Table 3. Dosidicus gigas. Analysis of variance of the element concentrations in different growth zones of statoliths. N: nucleus, PN: postnuclear zone, DZ: dark zone, PZ: peripheral zone

\begin{tabular}{|c|c|c|c|c|c|}
\hline \multirow[t]{2}{*}{ Element } & \multicolumn{4}{|c|}{ Range of element concentrations (ppm) } & \multirow[t]{2}{*}{$\mathrm{p}$} \\
\hline & $\mathrm{N}$ & $\mathrm{PN}$ & DZ & PZ & \\
\hline Strontium & $5477-7218$ & $5487-6868$ & $5572-6275$ & $5968-7433$ & 0.038 \\
\hline Barium & $3.5-10.5$ & $3.7-13.9$ & $3.8-9.4$ & $5.1-15.7$ & 0.004 \\
\hline Magnesium & $32.3-383$ & $29.1-94.2$ & $26.6-68.7$ & $22.7-547$ & 0.427 \\
\hline Sodium & $3589-5239$ & $3616-5519$ & $3380-5388$ & $2982-4421$ & 0.000 \\
\hline
\end{tabular}

\section{RESULTS}

\section{Age estimation and hatching date calculation}

All 18 individuals were immature, ranging from 258 to $517 \mathrm{~mm} \mathrm{ML}$ and 456 to $3719 \mathrm{~g} \mathrm{BW}$ (Table 1). Based on statolith aging, the smallest squid was 159 d old, while the oldest was $291 \mathrm{~d}$. Back-calculated hatching dates of the samples included autumn (March, April, May), spring (September, October, November), and winter cohorts (July; Table 1).

\section{Element concentrations and element:Ca ratios}

In addition to $\mathrm{Ca}$, $\mathrm{Sr}$ was the second-most abundant element, with concentrations ranging from 5871 to $6570 \mathrm{ppm}$ in the statoliths. The ratio $\mathrm{Sr}$ :Ca ranged from 14.8 to $16.4 \mathrm{mmol} \mathrm{mol}^{-1}$. Other element:Ca ratios are shown in Table 2. The element composition of statoliths showed no significant differences between females and males ( $p>0.05)$. All elements in different growth zones showed significant variations, except for Mg (Table 3).

\section{Element:Ca ratios in different growth zones and age classes}

$\mathrm{Sr}: \mathrm{Ca}$ ratios were higher in the $\mathrm{N}$, then decreased gradually to become lowest in the DZ and increased towards the PZ (Fig. 3a). Values in the N and PZ were significantly higher than in the DZ $(p<0.05)$.
Ba:Ca ratios in the PZ were significantly higher than those in the other zones (Figs. 3b \& 4b; $p<0.01$ ). No significant difference was found between the $\mathrm{N}$ and DZ ( $\mathrm{p}>0.05)$.

$\mathrm{Mg}$ :Ca ratios showed a decreasing trend along the transect from the core to the edge (Fig. 3c), and their values in the $\mathrm{N}$ were significantly higher than those in the other zones ( $p<0.01)$. $\mathrm{Na}$ :Ca ratios in the PZ were significantly lower than those in the other zones (Fig. 3d; p < 0.01). No significant differences in $\mathrm{Na}: \mathrm{Ca}$ ratios were found between the other zones ( $p>0.05)$.

The changes in element: $\mathrm{Ca}$ ratios with age for individual squid (Fig. 4) were almost the same as those in different growth zones.

\section{Element:Ca ratios in different hatching seasons}

The Sr:Ca ratio in the $\mathrm{N}$ was the only ratio found to be significantly different for squid hatching in the winter and autumn (Fig. 5a; p < 0.05). There were no significant differences of other element:Ca ratios in Dosidicus gigas statoliths from the 3 spawning seasons ( $p>0.05$ ). No significant difference of $\mathrm{Sr}$ :Ca ratios in the PN was found among the 3 spawning seasons ( $p>0.05)$, although their seasonal patterns were similar to those in the N (Fig. 5a). Ba:Ca ratios in the PN showed no significant difference among seasons (Fig. 5b; p > 0.05).

$\mathrm{Mg}$ : $\mathrm{Ca}$ ratios in the $\mathrm{N}$ of the autumn hatched squid were significantly higher than those of squid hatched in other seasons (Fig. $5 c_{i} p<0.05$ ). The values of $\mathrm{Mg}: \mathrm{Ca}$ in the other growth zones showed no significant differences between squid hatched in different seasons (Fig. 5c; p > 0.05).

The 4 growth zones in statoliths of squid hatched in different seasons showed no significant effects on Na:Ca (Fig. 5d; p > 0.05).

\section{Element:Ca ratios in PZ from different sampling locations}

$\mathrm{Sr}: \mathrm{Ca}$ ratios in statoliths in the subadult phase increased with decreased latitude, but no significant differences were found between them (Fig. 6a, p > 0.05). Ba:Ca and Mg:Ca had a similar distribution in statoliths from northern to southern locations, with values from the central waters being higher than those from northern and southern waters (Fig. 6b,c). Na:Ca 

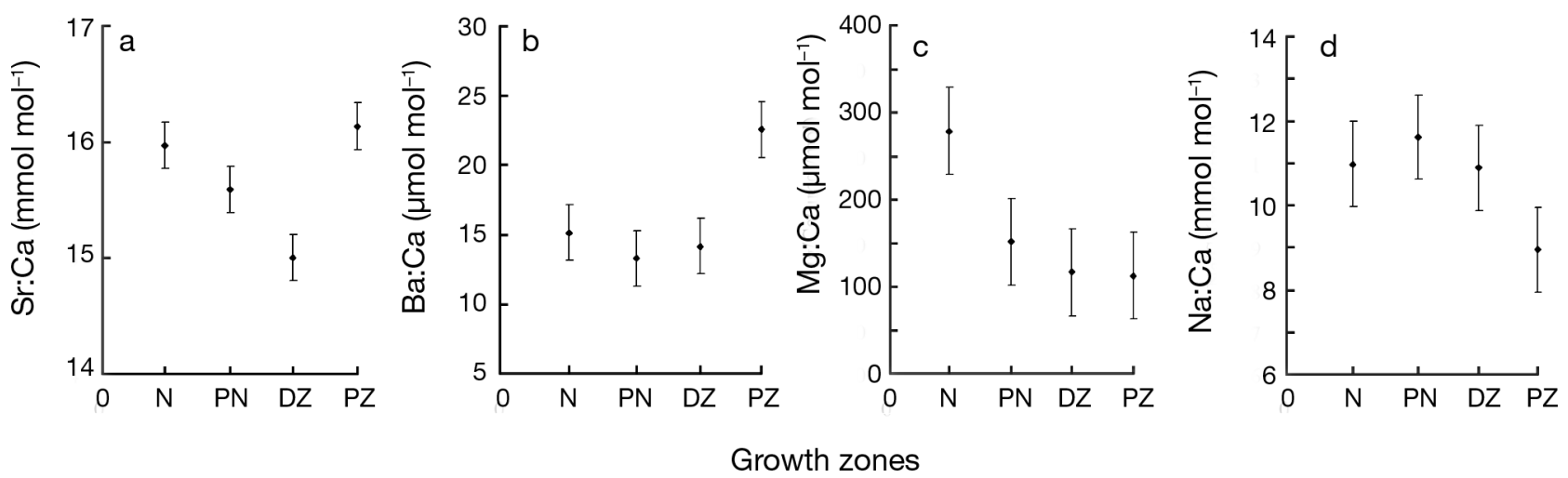

Fig. 3. Dosidicus gigas. Element:Ca ratios measured with laser ablation inductively coupled plasma mass spectrometry (LA-ICP$\mathrm{MS}$ ) in different gowth zones of statoliths from the nucleus to the edge. N: nucleus, PN: postnuclear zone, DZ: dark zone, PZ: peripheral zone
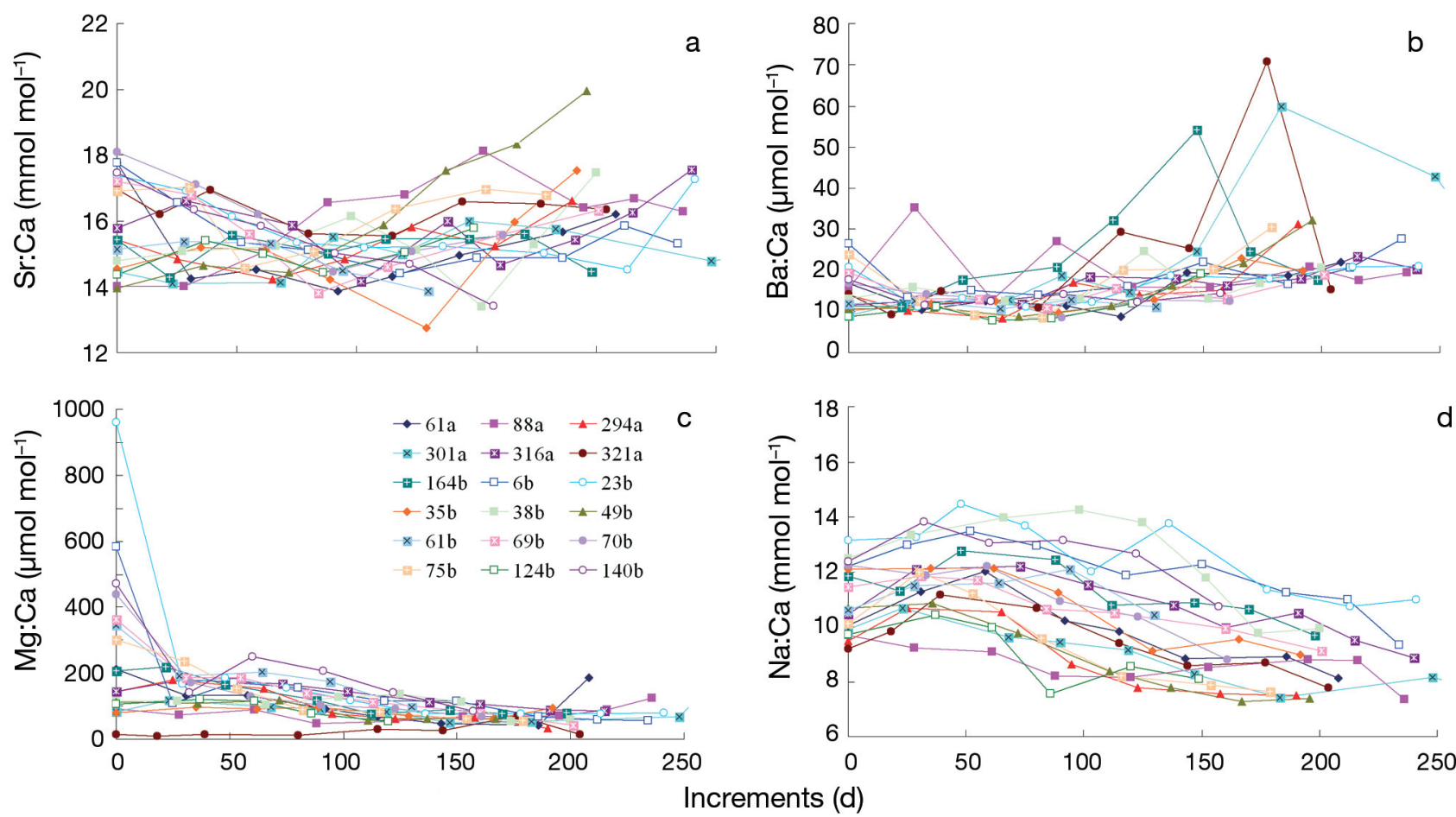

Fig. 4. Dosidicus gigas. Changes in element:Ca ratios measured with LA-ICP-MS with age (days). Each symbol represents 1 squid (see key in panel (c) and Table 1)

values in statoliths collected from northern, central, and southern waters were almost the same (Fig. 6d, p > $0.05)$.

\section{DISCUSSION}

Statolith microstructure of ommastrephid squids comprises the nucleus $(\mathrm{N})$, postnuclear zone $(\mathrm{PN})$, dark zone (DZ), and peripheral zone (PZ; Lipinski
1991). The formation of these zones generally corresponds with major ontogenetic stages. The $\mathrm{N}$ is the area within hatching increments that are associated with the embryonic stage (Arkhipkin 2005). The PN is associated with the larval phase of ontogenesis, the DZ represents the juvenile phase and the PZ corresponds to the subadult and adult phases (Arkhipkin \& Perez 1998, Arkhipkin 2005). Evidence supporting that the PN represents the larval stage of Dosidicus gigas was provided by Arkhipkin \& Mur- 

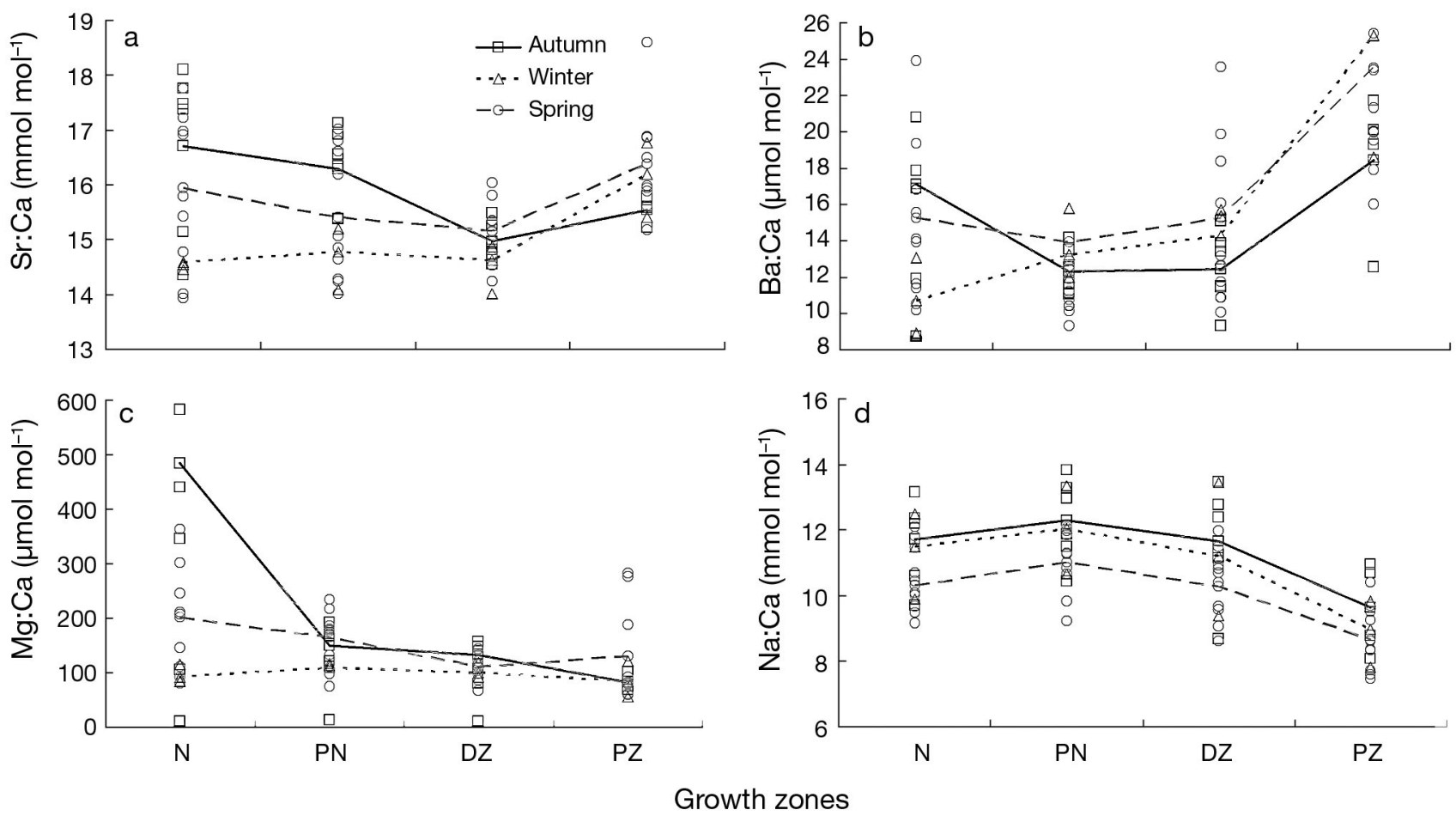

Fig. 5. Dosidicus gigas. Element:Ca ratios measured with LA-ICP-MS in different gowth zones during different hatching seasons. For abbreviations, see Fig. 3
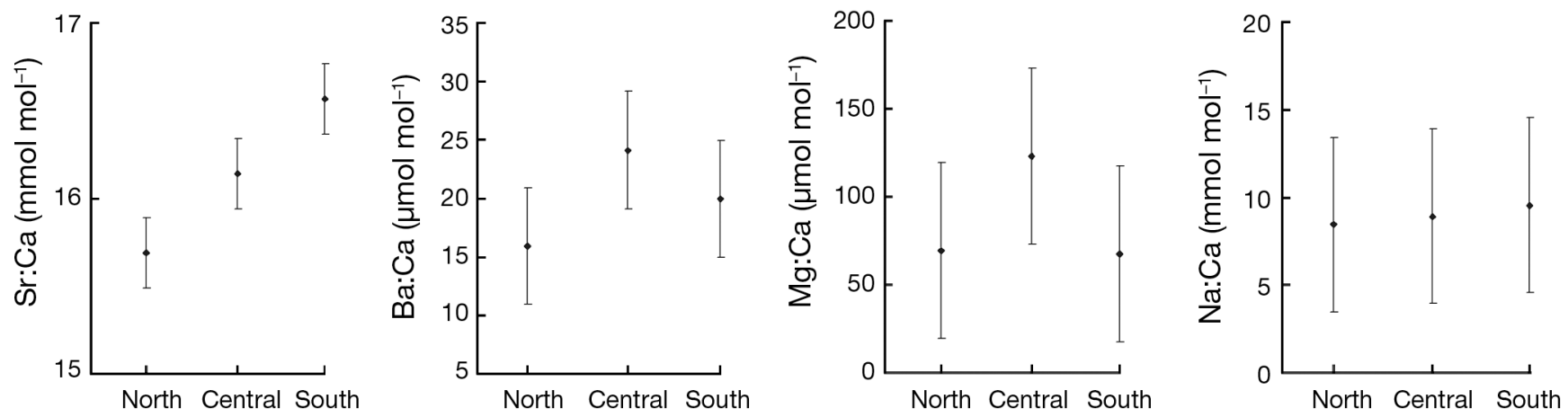

\section{Sampling locations}

Fig. 6. Dosidicus gigas. Element:Ca ratios measured with LA-ICP-MS in the peripheral zone of statoliths from squid sampled in different locations

zov (1986). According to these previous studies, we analyzed the variability in element:Ca ratios among different ontogenetic stages of $D$. gigas to reconstruct the environmental history these sampled squid had experienced.

In past years, microbeam methods of PIXE and the electron probe micro-analyzer (EPMA) have generally been used to analyze classified structure microchemistry (Ikeda et al. 1996, 2002a). However, these studies focussed on $\mathrm{Sr}$, the most abundant element incorporated into the aragonite matrix of statoliths. Recently, more scientists have paid attention to other trace elements like $\mathrm{Ba}, \mathrm{Mg}$, and $\mathrm{Mn}$, which cannot be detected accurately by these 2 methods. In this study, we used LA-ICP-MS to examine the elemental signature of Dosidicus gigas statoliths, since this method has a higher spatial resolution and lower detection limits.

$\mathrm{Sr}$ is a key element responsible for the deposition of cephalopod statoliths (Lipinski 1993). Sr:Ca ratios in statoliths of Dosidicus gigas (14.8 to $16.4 \mathrm{mmol} \mathrm{mol}^{-1}$ ) were higher than those of other squid such as Todarodes pacificus (8.5 to $10 \mathrm{mmol} \mathrm{mol}^{-1}$; Ikeda et al. 2003), Loligo gahi ( 8.0 mmol mol${ }^{-1}$; Arkhipkin et al. 2004), and Gonatus fabricii (6.3 to $8.1 \mathrm{mmol} \mathrm{mol}^{-1}$; Zumholz 
2005). We observed a U-shaped pattern of $\mathrm{Sr}: \mathrm{Ca}$, similar to Ommastrephes bartrami (Yatsu et al. 1998) and G. fabricii (Zumholz et al. 2007b).

$\mathrm{Sr}: \mathrm{Ca}$ ratios are believed to have negative correlations with ambient temperature (Arkhipkin et al. 2004). In our study, Sr:Ca ratios in statoliths of the embryonic stage were higher than those of paralarvae and juveniles, but same as those for the subadult stage (Fig. 3a). Sr:Ca ratios of paralavae and juvenile periods were relatively lower compared to those of the subadult stage, which is consistent with the life history of Dosidicus gigas. D. gigas are commonly found in from the surface to at least $1200 \mathrm{~m}$ depth (Nigmatullin et al. 2001), and the paralarvae and juvenile squid are found near the sea surface with relatively higher average ambient temperatures (upper temperature limits range from 15 to $32^{\circ} \mathrm{C}$ in surface waters (Nigmatullin et al. 2001). During the subadult and adult period, they migrate into the mesopelagic layers with lower temperatures (not lower than 4.0 to $4.5^{\circ} \mathrm{C}_{i}$ Nigmatullin et al. 2001), although they also occur in the superficial waters at night for feeding.

We assumed that the specimens had already inhabited the feeding ground and did not migrate into the spawning ground before maturity since they were all subadults (>150-180 mm ML, except 1 specimen of $122 \mathrm{~mm} \mathrm{ML} ;$ Yatsu et al. 1999) and immature (maturity stage 1 or 2). This suggests that no massive horizontal migrations occurred prior to the capture of the specimens used in this study. Excluding environmental changes brought about by horizontal migration, $\mathrm{Sr}: \mathrm{Ca}$ ratios in the statoliths of subadults from different sampling locations, i.e. northern part from $10^{\circ}$ to $12^{\circ} \mathrm{S}$, central part from $21^{\circ}$ to $26^{\circ} \mathrm{S}$, and southern part (south to $37^{\circ} \mathrm{S}$ ), were determined. An increasing $\mathrm{Sr}: \mathrm{Ca}$ ratio may be explained by a decrease in temperature from northern to southern waters in the study area, although no significant $\mathrm{Sr}$ :Ca differences were observed in the squid from different locations $(p>0.05)$. This result is similar to those of Ikeda et al. (2002b), who reported that $\mathrm{Sr}$ concentrations in Dosidicus gigas statoliths showed no significant difference between El Niño and non-El Niño years in Peruvian and Costa Rican waters for deep diel vertical migrations leading to widely ambient temperature variations.

Small variations may be worth considering, despite no significant $\mathrm{Sr}$ :Ca differences in larvae, juvenile, and subadult statoliths of squid hatching in the 3 seasons ( $p>0.05$ ). Among squid spawning in the 3 seasons, the $\mathrm{Sr}: \mathrm{Ca}$ ratio of larval squid spawning in autumn was highest, whereas the value was lowest in the subadult stages. Thus, we conclude that different stages might experience different ambient water environments.

The embryonic stage occurs before hatching, and individuals at this stage depend on their yolks. Thus, at this stage, the element signature of the statolith $\mathrm{N}$ is perhaps more likely to depend on squid from the same cohort, less affected by external factors because yolk composition may be influenced by genetic factors (Zumholz 2005). Yatsu et al. (1998) revealed that Sr and Ca concentrations in statoliths of Ommastrephes bartrami are probably affected in a different way during the embryonic period than during other ontogenetic stages. Bustamante et al. (2002) pointed out that the capsule membrane of Sepia officinalis acts as an efficient shield, protecting the embryo against metals like $\mathrm{Zn}$ and $\mathrm{Cd}$. The higher $\mathrm{Sr}: \mathrm{Ca}$ ratio during the embryonic period may not be due to ambient water conditions but rather to the yolk sac, as has been reported in salmonids (Kalish 1990) and Gonatus fabricii (Zumholz et al. 2007b). We found that Sr:Ca ratios in statoliths during the embryonic stage were different among squid spawning in the 3 seasons, but significant variation was only observed between autumn- and winter-spawning groups (Fig. 4a; p < 0.05). Thus, we can use Sr:Ca to discriminate the squid hatching seasons.

Ba:Ca ratios in statoliths of Dosidicus gigas (11.2 to $23.8 \mu \mathrm{mol} \mathrm{mol}^{-1}$ ) were higher than those reported for Gonatus fabricii (5.7 to $8.2 \mathrm{\mu mol} \mathrm{mol}^{-1}$; Zumholz 2005) and Loligo gahi (3.0 to $8.0 \mu \mathrm{mol} \mathrm{mol}^{-1}$; Arkhipkin et al. 2004). This variability may result from species differences rather than from other factors. Ba concentrations are considered to increase with depth. For corals and cephalopods, Ba has therefore been used as an indicator element for upwelling events (Lea et al. 1989, Arkhipkin et al. 2004). Arkhipkin et al. (2004) suggested that intensification of upwelling is responsible for the elevated levels of Ba in L. gahi statoliths collected from shelf waters around the Falkland Islands. Positive correlations of Ba:Ca in gastropod larval protoconchs (Zacherl et al. 2003b) and fish otoliths (Bath et al. 2000) with $\mathrm{Ba}: \mathrm{Ca}$ in the seawater were identified. Alternatively, Ba:Ca was considered a useful indicator for vertical movements of cephalopods (Arkhipkin et al. 2004). Thus an elevating trend of Ba:Ca in D. gigas statoliths can be confirmed by ontogenetic vertical migrations (OVMs) from the surface during paralarval and juvenile phases to mesopelagic waters in the subadult and adult periods. Similar results were found in G. fabricii statoliths (Zumholz 2005). Ba:Ca cannot be used to discriminate the 3 different spawning groups because there is no significant difference in different ontogenetic phases of D. gigas. However, it is useful to determine the autumn and spring spawning groups of L. gahi (Arkhipkin et al. 2004). Ba:Ca ratios in L. gahi (Arkhipkin et al. 2004) and Sepia officinalis (Zumholz et al. 2007a) statoliths were found to be negatively related to water temperature, but this was not found for $D$. gigas in our study. 
$\mathrm{Mg}$ is another important element for biomineralization in cephalopod statoliths, and its high concentrations are considered to be associated with the deposition of organic components into the statoliths (Morris 1991). It therefore would be expected to decrease correspondingly to the size of the cephalopod (Bettencourt \& Guerra 2000). Zumholz (2005) suggested that the Mg:Ca ratios of Gonatus fabricii were high in core regions and declined progressively towards the edge, probably reflecting decreasing growth rates from the core to the edge of the statoliths. In this study, similar to the Mg:Ca distribution for G. fabricii, the values of Mg:Ca gradually decreased from the $\mathrm{N}$ to the PZ. Arkhipkin et al. (2004) suggested that similar to coral skeletons, Mg:Ca in Loligo gahi statoliths was positively correlated with ambient water temperatures (Mitsuguchi et al. 1996). However, no such a relationship was found for Dosidicus gigas in our study. Like $\mathrm{Sr}: \mathrm{Ca}, \mathrm{Mg}$ :Ca can also be used to help identify whether squid hatched in autumn or winter.

Contrary to other element:Ca ratios, $\mathrm{Na}$ :Ca ratios in statoliths of Dosidicus gigas (8.6 to $12.8 \mathrm{mmol} \mathrm{mol}^{-1}$ ) were lower compared to values for Gonatus fabricii

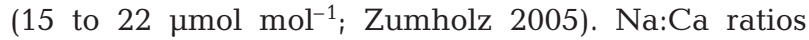
declined slightly from the paralarvae to adult phases. However, no significant variations were observed in squid hatched in different seasons, suggesting that the $\mathrm{Na}$ :Ca ratio cannot be used to distinguish individuals hatched in different seasons.

In conclusion, $\mathrm{Sr}: \mathrm{Ca}$ and $\mathrm{Mg}: \mathrm{Ca}$ of Dosidicus gigas statoliths were good indicators for distinguishing squid from autumn and winter spawning seasons. Distribution patterns of $\mathrm{Sr}: \mathrm{Ca}$ and $\mathrm{Ba}: \mathrm{Ca}$ in statoliths confirm that paralarvae and juvenile squid inhabit surface waters, while subadult squid migrate into deeper waters. An increasing Sr:Ca ratio of subadult squid could be explained by declining temperature gradients from northern to southern sampling locations. $\mathrm{Mg}$ :Ca ratios decreased progressively from the nucleus to the peripheral zone, which may be correlated with statolith growth rates. Elemental signatures can improve our understanding of the life history of D. gigas.

Acknowledgements. We appreciate the State Key Laboratory of Geological Processes and Mineral Resources, China University of Geosciences, for element analyses. Supports of scientific surveys made by New Century No. 52, Xin Jieli No. 8, and Zhe Yunyu No. 807 are gratefully acknowledged. This work was funded by the National Nature Science Foundation of China (NSFC40876090), the Innovation Program of Shanghai Municipal Education Commission (10YE127), and the 'Shu Guang' project (08GG14) from the Shanghai Municipal Education Commission and Shanghai Leading Academic Discipline Project (Project S30702). Y.C.'s involvement in the project was supported by the Shanghai Dongfang Scholar Program.

\section{LITERATURE CITED}

Alarcón-Muñoz R, Cubillos L, Gatica C (2008) Jumbo squid (Dosidicus gigas) biomass off central Chile: effects on Chilean hake (Merluccius gayi). Rep CCOFI 49:157-166

Argüelles J, Rodhouse PG, Villegas P, Castillo G (2001) Age, growth and population structure of jumbo flying squid Dosidicus gigas in Peruvian waters. Fish Res 54:51-61

Arkhipkin AI (2005) Statoliths as 'black boxes' (life recorders) in squid. Mar Freshw Res 56:573-583

Arkhipkin AI, Bizikov V (2000) Role of the statolith in functioning of the acceleration receptor system in squids and sepioids. J Zool (Lond) 250:31-55

Arkhipkin AI, Murzov SA (1986) Age and growth patterns of Dosidicus gigas (Ommastrephidae). In: Resources and prospects of utilization of squid stocks in the world ocean. VNIRO Press, Moscow, p 107-123

Arkhipkin AI, Perez J AA (1998) Life history reconstruction. In: Rodhouse PG, Dawe EG, O'Dor RK (eds) Squid recruitment dynamics. The genus Illex as a model, the commercial Illex species and influence on variability. FAO Fisheries Tech Pap 376. FAO, Rome, p 157-180

> Arkhipkin AI, Campana SE, FitzGerald J, Thorrold SR (2004) Spatial and temporal variation in elemental signatures of statoliths from the Patagonian longfin squid (Loligo gahi). Can J Fish Aquat Sci 61:1212-1224

Bath GE, Thorrold SR, Jones CM, Campana SE, McLaren JW, Lam JWH (2000) Sr and Ba uptake in aragonitic otolith of marine fish. Geochim Cosmochim Acta 64:1705-1714

Beck JW, Edwards RL, Ito E, Frederick W and others (1992) Sea-surface temperature from coral skeletal strontium/ calcium ratios. Science 257:644-647

Becker BJ, Fodrie FJ, McMillan PA, Levin LA (2005) Spatial and temporal variation in trace elemental fingerprints of mytilid mussel shells: a precursor to invertebrate larval tracking. Limnol Oceanogr 50:48-61

Bettencourt V, Guerra A (2000) Growth increments and biomineralization process in cephalopod statoliths. J Exp Mar Biol Ecol 248:191-205

Biemann M D, Piatkowski U (2001) Amounts and composition of trace elements in the statoliths of loliginid squids: reflection of environmental conditions? ICES CM K: 5

Bustamante P, Teyssié JL, Fowler SW, Cotret O, Danis B, Miramand P, Warnau M (2002) Biokinetics of zinc and cadmium accumulation and depuration at different stages in the life cycle of the cuttlefish Sepia officinalis. Mar Ecol Prog Ser 231:167-177

> Campana SE (1999) Chemistry and composition of fish otoliths: pathways, mechanisms and applications. Mar Ecol Prog Ser 188:263-297

Chen XJ, Zhao XH (2005) Catch distribution of jumbo flying squid and its relationship with SST in the offshore waters of Chile. Mar Fish 27:173-176

- Clarke MR (1978) The cephalopod statolith — an introduction to its form. J Mar Biol Assoc UK 58:701-712

Dawe EG, Natsukari Y (1991) Light microscopy. In: Jereb P, Ragonese S, von Boletzky S (eds) Squid age determination using statoliths. Section 2: practical procedures of squid ageing using statoliths. A laboratory manual. Proc Int Workshop, Istituto di Tecnologia della Pesca e del Pescato. (ITPP-CNR), Mazara del Vallo, Italy, 9-14 October 1989. NTR-ITPP. Spec Publ 1, p 83-95

Ibáñez CM, Cubillos LA (2007) Seasonal variation in the length structure and reproductive condition of the jumbo squid Dosidicus gigas (d'Orbigny, 1835) off central-south Chile. Sci Mar 71:123-128

Ikeda Y, Arai N, Sakamoto W, Kidokoro H, Yoshida K (1996) 
Relationship between statoliths and environmental variables in cephalopods. Int J PIXE 6:339-345

Ikeda Y, Okazaki J, Sakurai Y, Sakamoto W (2002a) Periodic variation in $\mathrm{Sr} / \mathrm{Ca}$ ratios in statoliths of the Japanese common squid Todarodes pacificus Steenstrup, 1880 (Cephalopoda: Ommastrephidae) maintained under constant water temperature. J Exp Mar Biol Ecol 273:161-170

Ikeda Y, Yatsu A, Arai N, Sakamoto W (2002b) Concentration of statolith trace elements in the jumbo flying squid during El Niño and non-El Niño years in the eastern Pacific. J Mar Biol Assoc UK 82:863-866

Ikeda Y, Arai N, Kidokoro H, Sakamoto W (2003) Strontium: calcium ratios in statoliths of Japanese common squid Todarodes pacificus (Cephalopoda: Ommastrephidae) as indicators of migratory behavior. Mar Ecol Prog Ser 251:169-179

Jackson GD (1994) Application and future potential of statolith increment analysis in squids and sepioids. Can J Fish Aquat Sci 51:2612-2625

Kalish JM (1990) Use of otolith microchemistry to distinguish the progeny of sympatric anadromous and non-anadromous salmonids. Fish Bull 88:657-666

Lea DW, Shen GT, Boly EA (1989) Coralline barium records temporal variability in equatorial Pacific upwelling. Nature 340:373-376

Lipinski M (1979) Universal maturity scale for the commercially important squids. The results of maturity classification of the Illex illecebrosus population for the years 19731977. Int Comm N Atl Fish Res Doc, 70/2/38, Ser No 5364

Lipinski MR (1991) Scanning electron microscopy (SEM) and chemical treatment. In: Jereb P, Ragonese S, von Boletzky $\mathrm{S}$ (eds) Squid age determination using statoliths. Section 2: practical procedures of squid ageing using statoliths. A laboratory manual. Proc Int Workshop, Istituto di Tecnologia della Pesca e del Pescato (ITPP-CNR), Mazara del Vallo, Italy, 9-14 October 1989. NTR-ITPP. Spec Publ 1, p 97-112

Lipinski MR (1993) The deposition of statoliths: a working hypothesis. In: Okutani T, O'Dor R, Kubodera T (eds) Recent advances in cephalopod fisheries biology. Tokai University Press, Tokyo, p 241-262

Liu BL, Chen XJ, Ma J, Qian WG (2010a) Review of studies of the microchemical structure of cephalopod statoliths. J Fish China 34:316-321

Liu BL, Chen XJ, Lu HJ, Chen Y, Qian WG (2010b) Fishery biology of the jumbo flying squid Dosidicus gigas off the Exclusive Economic Zone of Chilean waters. Sci Mar 74: 687-695

Mitsuguchi T, Matsumoto E, Abe O, Uchida T, Isdale PJ (1996) $\mathrm{Mg} / \mathrm{Ca}$ thermometry in coral skeletons. Science 274:961-963

Morris CC (1991) Statocyst fluid composition and its effects on calcium carbonate precipitation in the squid Alloteuthis subulata (Lamarck, 1798): towards a model for biomineralization. Bull Mar Sci 49:379-388

Nesis KN (1983) Dosidicus gigas. In: Boyle PR (eds) Cephalopod life cycles: species accounts, Vol I. Academic Press, London, p 215-231

Nigmatullin CM, Nesis KN, Arkhipkin AI (2001) A review of the biology of the jumbo squid Dosidicus gigas (Cepha-

Editorial responsibility: Hans Heinrich Janssen, Oldendorf/Luhe, Germany lopoda: Ommastrephidae). Fish Res 54:9-19

Radtke RL (1983) Chemical and structural characteristic of statoliths from the short-finned squid Illex illecebrosus. Mar Biol 76:47-54

Rocha F (1997) Cephalopods in Chilean waters: a review. Malacol Rev 30:101-113

> Rocha F, Vega M (2003) Overview of cephalopod fisheries in Chilean waters. Fish Res 60:151-159

Rodhouse PG, Robinson K, Gajdatsy SB, Daly HI, Ashmore MJS (1994) Growth, age structure and environmental history in the cephalopod Martialia hyadei (Teuthoidea: Ommastrephidae) at the Atlantic Polar Frontal Zone and on the Patagonian Shelf Edge. Antarct Sci 6:259-267

- Tafur R, Villegas P, Rabí M, Yamashiro C (2001) Dynamics of maturation, seasonality of reproduction and spawning grounds of the jumbo squid Dosidicus gigas (Cephalopoda: Ommastrephidae) in Peruvian waters. Fish Res 54:33-50

Taipe A, Yamashiro C, Mariategui L, Rojas P, Roque C (2001) Distribution and concentrations of jumbo flying squid (Dosidicus gigas) off the Peruvian coast between 1991 and 1999. Fish Res 54:21-32

Thorrold SR, Jones GP, Hellberg ME, Burton RS and others (2002) Quantifying larval retention and connectivity in marine populations with artificial and natural marks. Bull Mar Sci 70:291-308

> Yatsu A, Midorikawa S, Shimada T, Uozumi Y (1997) Age and growth of the neon flying squid, Ommastrephes bartrami, in the North Pacific Ocean. Fish Res 29:257-270

Yatsu A, Mochioka N, Morishita K, Toh H (1998) Strontium/ calcium ratios in statoliths of the neon flying squid, Ommastrephes bartrami (Cephalopoda), in the North Pacific Ocean. Mar Biol 131:275-282

Yatsu A, Yamanaka KI, Yamashiro C (1999) Tracking experiments of the jumbo squid, Dosidicus gigas, with an ultrasonic telemetry system in the eastern Pacific Ocean. Bull Natl Res Inst Far Seas Fish 36:55-60

Zacherl DC, Manriquez PH, Paradis GD, Day RW and others (2003a) Trace elemental fingerprinting of gastropod statoliths to study larval dispersal trajectories. Mar Ecol Prog Ser 248:297-303

Zacherl DC, Paradis GD, Lea DW (2003b) Barium and strontium uptake into larval protoconchs and statoliths of the marine neogastropod Kelletia kelletii. Geochim Cosmochim Acta 67:4091-4099

Zumholz K (2005) The influence of environmental factors on the micro-chemical composition of cephalopod statoliths. $\mathrm{PhD}$ thesis, University of Kiel

Zumholz K, Hansteen TH, Piatkowski U, Croot PL (2007a) Influence of temperature and salinity on the trace element incorporation into statoliths of the common cuttlefish (Sepia officinalis). Mar Biol 151:1321-1330

Zumholz K, Klügel A, Hansteen TH, Piatkowski U (2007b) Statolith microchemistry traces environmental history of the boreoatlantic armhook squid Gonatus fabricii. Mar Ecol Prog Ser 333:195-204

Zúñiga M J, Cubillos L A, Ibáñez C (2008) A regular pattern of periodicity in the monthly catch of jumbo squid (Dosidicus gigas) along the Chilean coast (2002-2005). Ciens Mar 34:91-99

Submitted: October 22, 2010; Accepted: February 25, 2011

Proofs received from author(s): May 4, 2011 